\title{
DNA polymorphisms in new isolates of 'Deinococcus radiopugnans'
}

\author{
C. Ian Masters, ${ }^{1}$ Robert G. E. Murray, ${ }^{2}$ Bevan E. B. Moseley ${ }^{3}$ and \\ KENNETH W. MINTON ${ }^{1 *}$ \\ 'Department of Pathology, F. E. Hébert School of Medicine, Uniformed Services University of the Health Sciences, \\ Bethesda, MD 20814-4799, USA \\ ${ }^{2}$ Department of Microbiology and Immunology, The University of Western Ontario, London N6A 5C1, Canada \\ ${ }^{3}$ Agricultural and Food Research Council, Institute of Food Research, Reading Laboratory, Shinfield, Reading, \\ Berkshire RG2 9AT, UK
}

(Received 26 October 1990; revised 25 February 1991; accepted 25 March 1991)

\begin{abstract}
Nineteen new Deinococcus isolates from soil, 18 of which were from samples immediately adjacent to a lake in Nottingham, UK, were characterized by conventional criteria, and found to be identical to each other and to conform most closely to the species $D$. radiopugnans. However, we detected three different restriction enzyme activities in three different isolates. Because of this suggestion of heterogeneity, we examined the isolates for restriction fragment length polymorphisms (RFLPs). RFLP analysis of the 19 original isolates, using three different probes, distinguished 17 divergent groups. This extraordinary diversity cannot be attributed to geographical differences, nor to the method of isolation, which employed UV-radiation selection.
\end{abstract}

\section{Introduction}

The genus Deinococcus (Brooks \& Murray, 1981; Murray, 1986; Murray \& Brooks, 1986) consists of four species of nonsporing bacteria that share an exceptional resistance to UV and ionizing radiation (Moseley, 1983) and to desiccation (Murray, 1986; Sanders \& Maxcy, 1979). Since the first isolation of the genus type strain, $D$. radiodurans $\mathrm{R} 1$ (Anderson et al., 1956), from irradiated canned meat, the other species of this genus which have been recognized are: $D$. radiopugnans, from irradiated haddock tissue in Massachusetts (Davis et al., 1963) and from weathered granite in Antarctica (Counsell \& Murray, 1986); D. radiophilus, from irradiated Bombay duck in India (Lewis, 1971); and D. proteolyticus, from irradiated faeces of Llama glama (Kobatake et al., 1973) and irradiated sewage sludge cake and animal feeds in Japan (Ito et al., 1983). In contrast to the latter three species, $D$. radiodurans has been isolated many times with a world-wide distribution (Murray, 1986).

The diversity of natural bacterial populations is believed to be far greater than previously detected by culture-dependent laboratory methods (Ward et al., 1990, and citations therein). Recent evidence in favour of this proposition has been obtained by cloning and

Abbreviation: RFLP, restriction fragment length polymorphism. sequencing of $16 \mathrm{~S}$ rRNAs directly from natural biomass in two bacterial populations, Sargasso sea bacterioplankton (Giovannoni et al., 1990) and a cyanobacterial mat from Yellowstone hot springs (Ward et al., 1990). One obstacle to detecting the full range of natural bacterial diversity is that laboratory-based culture is itself a form of selection. Another obstacle is that closely related organisms may appear identical by various taxonomic criteria, and yet be quite diverse in genetic organization. In the current communication we characterized every Deinococcus isolate obtained from a single source, via a stringent selection method. Although the organisms were identical by conventional criteria we found an extraordinary diversity of DNA polymorphisms.

\section{Methods}

Bacterial strains and plasmids. Previously isolated strains and plasmids are listed in Table 1. Deinococcus spp. were grown in TGY nutrient broth $(0.8 \%$ tryptone, $0.4 \%$ yeast extract, $0.1 \%$ glucose $)$ or on TGY plates, solidified by $1.5 \%(\mathrm{w} / \mathrm{v})$ agar. Escherichia coli was grown at $37^{\circ} \mathrm{C}$ in LB broth.

Isolation of deinococci. Solid and water samples (1-2 g) were collected from various sites and mixed with $15 \mathrm{ml}$ sterile $67 \mathrm{mM}$-potassium phosphate buffer, $\mathrm{pH} 7 \cdot 0$. Debris and soil were allowed to settle out and the supernatant placed in a sterile glass Petri dish to a depth no greater

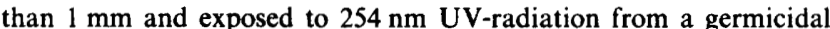


Table 1. Bacterial strains and plasmids

\begin{tabular}{|c|c|}
\hline Strain or plasmid* & Description (reference) \\
\hline \multicolumn{2}{|l|}{ Deinococcus } \\
\hline $\begin{array}{l}\text { D. radiodurans } R 1 \\
\text { (UWO } 288^{\mathrm{T}} \text {; ATCC 13939) }\end{array}$ & Brooks \& Murray (1981) \\
\hline $\begin{array}{l}\text { D. radiodurans SARK } \\
\text { (UWO 298) }\end{array}$ & Brooks \& Murray (1981) \\
\hline $\begin{array}{l}\text { D. radiopugnans } \\
\text { (UWO 293T ; ATCC 19172) }\end{array}$ & Brooks \& Murray (1981) \\
\hline $\begin{array}{l}\text { D. radiophilus } \\
\text { (UWO } 1055^{\mathrm{T}} \text {; ATCC 27603) }\end{array}$ & Brooks \& Murray (1981) \\
\hline $\begin{array}{l}\text { D. proteolyticus } \\
\text { (UWO 1056 })\end{array}$ & Brooks \& Murray (1981) \\
\hline $\begin{array}{l}\text { Escherichia coli } \\
\text { MM294 (ATCC 33625) }\end{array}$ & K12 derivative \\
\hline \multicolumn{2}{|l|}{ Plasmids } \\
\hline pUE58 & $\begin{array}{l}5.6 \mathrm{~kb} \text { EcoRI fragment of } m t c A^{+} D . \text { radiodurans } \\
\mathrm{R} 1 \text { chromosomal DNA, cloned in pAT153 } \\
\text { (Al-Bakri et al., 1985) }\end{array}$ \\
\hline pUE200 & $\begin{array}{l}8.1 \mathrm{~kb} \text { EcoRI-Sal I fragment of uvsCDE } D \text {. } \\
\text { radiodurans R1 chromosomal DNA, cloned in } \\
\text { pAT153 }\end{array}$ \\
\hline pS19 & $\begin{array}{l}\text { Full-length clone of natural } D \text {. radiodurans SARK } \\
\text { plasmid pUE11 }(45 \mathrm{~kb} \text { ), into the EcoRV site of } \\
\mathrm{Km}^{\mathrm{R}} \text { ColE1 derivative pS27 (Smith } \text { et al., } \\
\text { 1989) }\end{array}$ \\
\hline
\end{tabular}

- UWO, University of Western Ontario culture collection, London, Ontario, Canada; ATCC, American Type Culture Collection, Rockville, Maryland, USA.

lamp at a dose rate of $1.05 \mathrm{~J} \mathrm{~m}^{-2} \mathrm{~s}^{-1}$. Samples were taken after 15 and $20 \mathrm{~min}$ of irradiation (945 and $1260 \mathrm{~J} \mathrm{~m}^{-2}$ total fluence, respectively), plated on TGY agar, and incubated at $30^{\circ} \mathrm{C}$. Red-pigmented colonies were selected and colony isolates derived from them.

Phenotypic characterization. (i) UV resistance was assesed by the agar plate streak test (Naumovski \& Friedberg, 1982), with the modification that higher UV fluences were employed. (ii) UV survival curves were obtained as described by Moseley \& Evans (1983). (iii) Measurement of DNA G $+\mathrm{C}$ content was by thermal denaturation (Marmur \& Doty, 1962). Salmon sperm DNA ( $43 \mathrm{~mol} \% \mathrm{G}+\mathrm{C}$ ) was used as control. (iv) $\beta$-Galactosidase was assayed as previously described (Lennon \& Minton, 1990). (v) Electron microscopy was performed as described by Brooks et al. (1980). (vi) Natural transformability was assessed as follows. All isolates were plated on TGY agar containing $25 \mu \mathrm{g}$ rifampicin $\mathrm{ml}^{-1}$. Spontaneous $\mathrm{Rif}^{\mathbb{R}}$ mutants were selected and DNA prepared from them. All original Rif ${ }^{S}$ isolates, as well as $\operatorname{Rif}^{S} D$. radiodurans strains $\mathrm{R} 1$ and SARK, were transformed with their own $\left(\right.$ Rif $\left.^{R}\right)$ DNA, as described by Tirgari \& Moseley (1980). Transformants were selected on TGY plates containing $25 \mu \mathrm{g}$ rifampicin $\mathrm{ml}^{-1}$. (vii) Diamino acids in the peptidoglycan layer were determined as follows. Peptidoglycan cell walls were prepared according to Schleifer \& Kandler (1972); $1 \mathrm{mg}$ of peptidoglycan was then hydrolysed in $6 \mathrm{M}-\mathrm{HCl}$ at $110^{\circ} \mathrm{C}$ for $18 \mathrm{~h}$, and analysed in a Beckman model $120 \mathrm{C}$ amino acid analyser.

Screening for restriction endonucleases. Plateau-phase cultures were harvested and washed with TE buffer (10 mM-Tris, $1 \mathrm{~mm}$-EDTA), resuspended in $10 \mathrm{ml} 10 \mathrm{~mm}$-Tris/ $\mathrm{HCl} \mathrm{pH} \mathrm{7.5,} 1 \mathrm{~mm}$-EDTA, $1 \mathrm{~mm}-$ phenylmethylsulphonyl fluoride, and lysed by French press at 20000 p.s.i. $(138 \mathrm{MPa})$ at $4{ }^{\circ} \mathrm{C}$. Cell debris was removed by centrifugation at
$27000 \mathrm{~g}$ for $10 \mathrm{~min}$. Restriction endonucleases were detected by incubating aliquots of supernatant with $1 \mu \mathrm{g}$ of DNA $(\lambda, \mathrm{pBR} 322$ and $\phi \mathrm{X} 174)$ in a final volume of $20 \mu \mathrm{l}$ with $10 \mathrm{mM}-\mathrm{MgCl}_{2}, 10 \mathrm{mM}-\mathrm{Tris} / \mathrm{HCl}$ pH 7.8, 1 mM-dithiothreitol, $0-100 \mathrm{~mm}-\mathrm{NaCl}$ at $37^{\circ} \mathrm{C}$ for $2 \mathrm{~h}$. Cleavage products were resolved by agarose gel electrophoresis $(0.6-0.8 \%)$ and the calculated DNA fragment sizes compared with restriction patterns of other known restriction endonucleases.

Assessment of polar lipids. The cultures of each isolate grown in TGY broth were harvested, extracted using the procedure of Bligh \& Dyer (1959), and the extracts submitted to one-dimensional thin-layer chromatography (TLC) on $20 \times 20 \mathrm{~cm}$ plates coated with $0.25 \mathrm{~mm}$ thick silica gel G-25. The two solvent systems and several detection reactions applied to the developed plates were those of Counsell \& Murray (1986). Solvent 1 was chloroform/methanol/water $(65: 25: 4$, by vol.) and solvent 2 was chloroform/acetone/methanol/acetic acid/water (10:4:2:2:1, by vol.). Extracts of a set of Deinococcus reference strains, $D$. radiodurans SARK UWO $298, D$. radiophilus UWO 1055T, D. radiopugnans UWO $293^{\mathrm{T}}$ and $D$. proteolyticus UWO $1056^{\mathrm{T}}$ were run on the same TLC plates for comparison.

DNA purification and manipulations. DNA isolation procedures, enzymic reagents, electrophoresis, Southern blotting, hybridization, washing of blots, autoradiography, and removal of probe from blots were as described by Lennon \& Minton (1990). For most Southern blot experiments $3 \mu \mathrm{g}$ samples of $\mathrm{CsCl}$-purified chromosomal DNAs were electrophoresed on $0.8 \%$ agarose horizontal gels at $1.5 \mathrm{~V} \mathrm{~cm}-1$. Hybridization with ${ }^{32} \mathrm{P}$-labelled probe employed $10^{6}$ c.p.m. ml ${ }^{-1}$ in $50 \%(\mathrm{v} / \mathrm{v})$ formamide for $18 \mathrm{~h}$ at $37^{\circ} \mathrm{C}$. Blots were washed at high stringency with a final washing at $60^{\circ} \mathrm{C}$ in $15 \mathrm{mM}-\mathrm{NaCl}, 1.5 \mathrm{mM}-$ sodium citrate, $0 \cdot 1 \%$ sodium dodecyl sulphate. 


\section{Results}

\section{Isolation of Deinococcus strains}

Fifteen samples, 1-2 $\mathrm{g}$ each, from various locations within the UK were heavily UV-irradiated, as described in Methods. Four locations (sites 1, 4, 5 and 6) yielded an overall total of 19 Deinococcus-like red-pigmented colonies. They were all from soil taken from very damp areas. Isolate $1 / 10$ was found in Edinburgh, next to a stream. Isolates $4 / 1$ through $4 / 16,5 / 1$ through $5 / 14$, and $6 / 1$ were from three locations (sites 4, 5 and 6), all within a $20 \mathrm{~m}^{2}$ area next to a lake in Nottingham. By streak test all 19 isolates were UV resistant. The UV-radiation survival curves of 14 isolates are shown in Fig. 1. Also included in this figure is $D$. radiodurans $\mathrm{R} 1$ and the UV-sensitive $D$. radiodurans $\mathrm{R} 1$ derivative, strain UVS78, that lacks two UV endonuclease repair pathways (Evans \& Moseley, 1983). The high UV resistance of the new isolates is similar to and characteristic of all known deinococcal species (Moseley, 1983).

\section{Identification of new strains}

The four recognized species of Deinococcus are quite similar in phenotype, although distinguishable by a number of characteristics (Murray, 1986). In common with all deinococci, all 19 current isolates showed the following: (i) dyads of cocci with Gram stain variability, predominantly Gram positive during the exponential phase; (ii) a very high DNA $\mathrm{G}+\mathrm{C}$ content, of $67.5 \pm 1.5 \mathrm{~mol} \%$; and (iii) production of catalase. All the current isolates differed from $D$. radiodurans, but not from the other three Deinococcus species, in not being naturally transformable by DNA from spontaneous $\operatorname{Rif}^{R}$ mutants of the same isolates. All the current isolates produced $\beta$-galactosidase, similar only to $D$. radiopugnans. These observations suggest assignment of all of the new isolates to $D$. radiopugnans, as only this species meets these criteria: red-pigmented radiation-resistant cocci with very high DNA $\mathrm{G}+\mathrm{C}$ content, that are nontransformable and produce $\beta$-galactosidase. In addition, DNA from $D$. radiopugnans (UWO $293^{\mathrm{T}}$ ) hybridized strongly to DNA from the new isolates, but not to DNA from $D$. radiodurans $\mathrm{R} 1, D$. radiodurans SARK, $D$. proteolyticus, or E. coli (Fig. 2). This observation supports the assignment of the new isolates to $D$. radiopugnans.

Five representative isolates were selected for more detailed characterization: the isolate from site $1(1 / 10)$, two isolates from site $4(4 / 1$ and $4 / 12)$, one isolate from site $5(5 / 3)$, and the isolate from site $6(6 / 1)$. It should be noted that three of these sites $(4,5$, and 6$)$ were essentially the same, as these soil samples were collected within a few metres of each other. Micrographs of thin

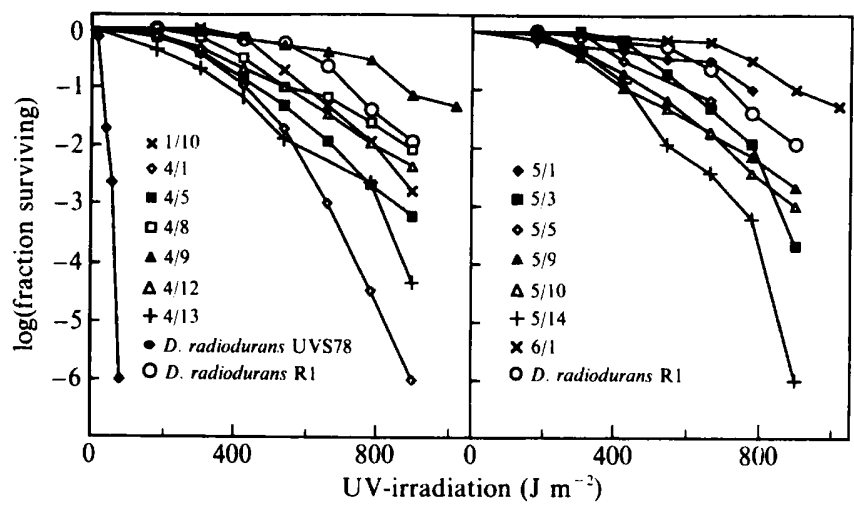

Fig. 1. Survival of the new isolates following UV-irradiation.

sections of the five isolates were identical, showing cocci with a complex cell wall profile with an outer membrane displaying a looped appearance widely separated from a thick peptidoglycan layer, features typical of the genus. Fig. 3 shows a representative micrograph of one of these isolates. The peptidoglycan layer is not uniformly smooth, but has irregularities every $15-18 \mathrm{~nm}$, indicative of fenestrations that are found in only two species, $D$. radiodurans and D. radiopugnans (Brooks et al., 1980; Brooks \& Murray, 1981; Murray, 1986). A well developed S-layer, a feature of $D$. radiodurans, was not present. The diamino acid in the peptidoglycan of all five isolates was ornithine, an unusual feature characteristic of all deinococci. None of the five new isolates grew on $5 \%(\mathrm{w} / \mathrm{v}) \mathrm{NaCl}$, distinguishing them from $D$. radiophilus, and none produced acid from glucose, distinguishing them from $D$. proteolyticus. All five isolates reduced nitrate, similar only to $D$. radiopugnans.

All species of Deinococcus contain large quantities of polar lipids, mostly phosphoglycolipids (Counsell \& Murray, 1986; Huang \& Anderson, 1989). The five isolates examined showed polar lipid profiles that were identical to each other (Fig. 4). The profile most closely resembled $D$. radiopugnans. Distinguishing features in solvent system 1 (Fig. $4 a$ ) were two prominent and closely adjacent phospholipids at $R_{F}$ approx. 0.35 present in the new isolates as well as in $D$. radiopugnans and $D$. radiodurans; and a phospholipid at $R_{F}$ approx. 0.56, which was present only in the new isolates and in $D$. radiopugnans and $D$. proteolyticus (Fig. $4 b$ ). Solvent system 2 showed a phospholipid at $R_{F} 0.35$ present only in the new strains and $D$. radiopugnans (Fig. $4 c, d$ ) and another at $R_{F} 0.57$ present only in the new strains and in $D$. proteolyticus and $D$. radiopugnans. The observations on these five isolates are most compatible with the assignment to $D$. radiopugnans. 

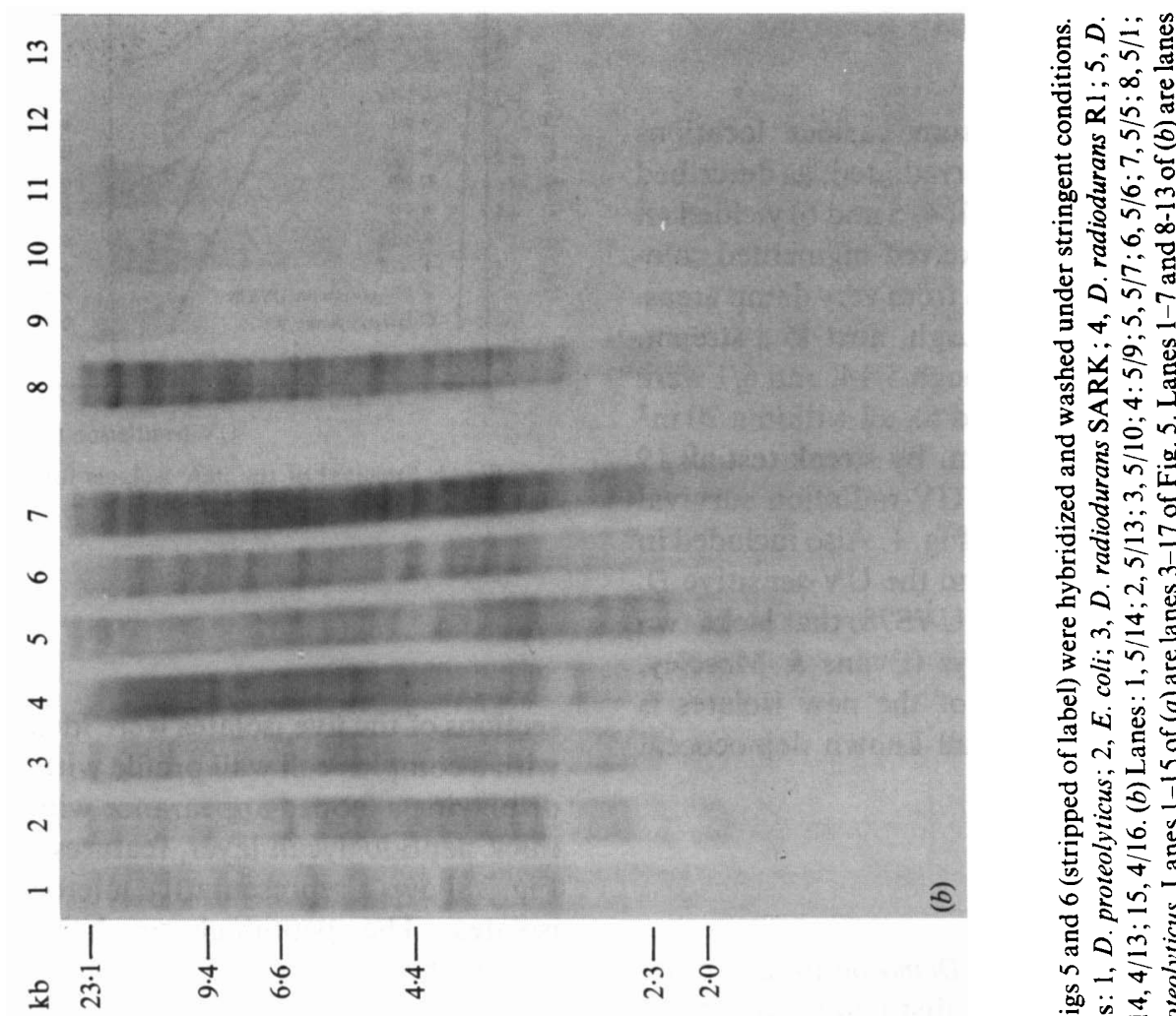

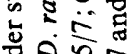
5 的I

苾会恋

然莳

उ芯苍的

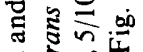

चू ڤ

总部 这管

的齐

芌告

它 包范 은

芯争 을 吾 幽守 g $n=\frac{\gamma}{\sigma}$ 品 要茫

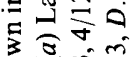
의 范三立

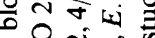

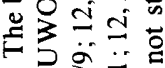
है

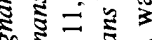

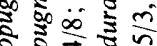

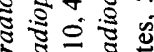
0完宁 ธ人。 台菏菏 원 ह 品茫范

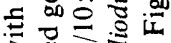
3 응 迸 형 임

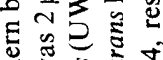
ข ชี i क

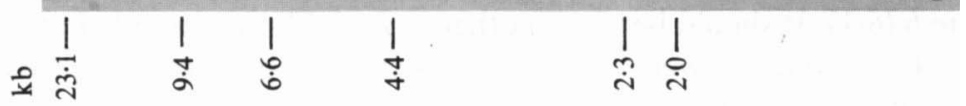

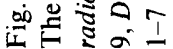




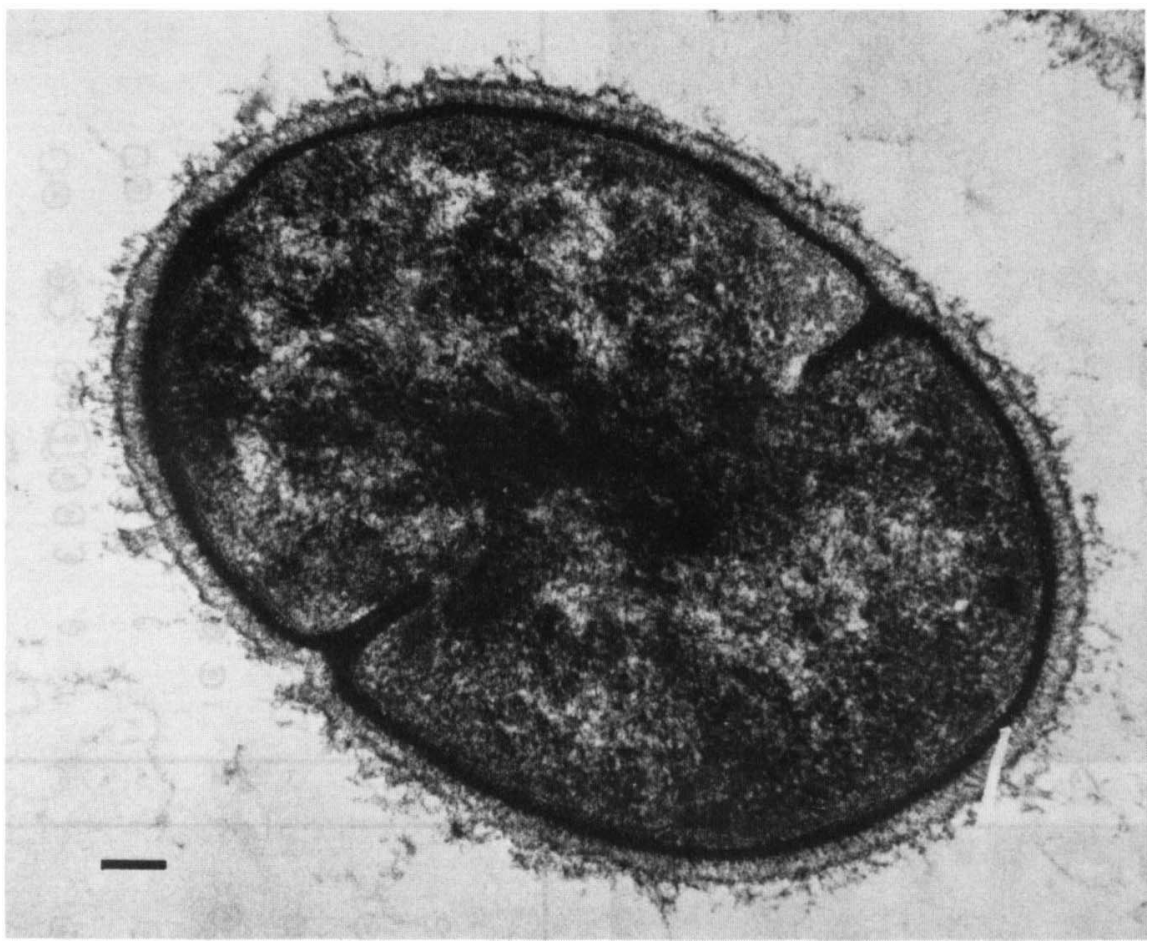

Fig. 3. Thin section electron micrograph of strain $1 / 10$ (fixed using $\mathrm{OsO}_{4}$ ). Bar, $100 \mathrm{~nm}$.

\section{Restriction endonucleases in the new D. radiopugnans isolates}

The 19 new isolates were evaluated for the presence of restriction endonucleases, as described in Methods. Strain 4/9 contained an isoschizomer of XhoII; strain 5/3 contained an isoschizomer of $P v u I$; and strain $6 / 1$ contained an isoschizomer of BstEII. No restriction enzyme activities were detected in the other 16 isolates. The activities of all three restriction endonucleases were optimal at approximately $37^{\circ} \mathrm{C}$ at $50 \mathrm{~mm}-\mathrm{NaCl}$ (data not shown). The Bst EII isoschizomer found in isolate 6/1 could be useful since Bst EII reactions are performed at $\geq 50^{\circ} \mathrm{C}$.

\section{Restriction fragment length polymorphisms}

The first suggestion of heterogeneity amongst these isolates was the presence of three different restriction enzyme activities in three different isolates, as described above. To further differentiate the colony isolates, we employed analysis of restriction fragment length polymorphisms (RFLPs), a techique that has recently proved useful for distinguishing strains in a variety of bacterial species (Kaijalanin \& Lindstrom, 1989, and citations therein). Southern blots of EcoRI-cleaved genomic DNA were hybridized with the three different probes described in Table 1: pUE58, pUE200 and pS19.
Cross-hybridization of these probes to other previously described species of Deinococcus, as well as the new isolates, occurred under stringent conditions (Figs 5 and 6). All the known species varied from each other as expected, but the new strains showed unexpected variety. While many isolates appeared different by hybridization to two or all three of the probes, differences between some of the strains were limited to only one of the three probes used; for example strains $4 / 8,4 / 9$ and $4 / 11$ had identical patterns for pUE58 and pUE200 but 4/9 differed when probed with pS19.

The chromosomal probes, pUE58 and pUE200, permitted differentiation of the 19 isolates into 12 RFLP groups (Table 2). Polymorphisms detected with the SARK plasmid probe, pS19, increased the number of polymorphism groups from 12 to 17 . Cross-hybridization of these three probes to genomic DNA of the other species and the new isolates was not as prominent as hybridization to the $D$. radiodurans strains; however, hybridization was distinct and highly polymorphic.

UV-irradiation was used as the selective agent to acquire these new deinococcal isolates. The great majority of all known Deinococcus strains have been isolated using similar protocols (UV- or X-irradiation; Murray, 1986). Thus, the chromosomal variation could be due to the selection procedure itself, as UV might induce mutations which are detected as RFLPs. To investigate this hypothesis, one of the new D. radiopug- 

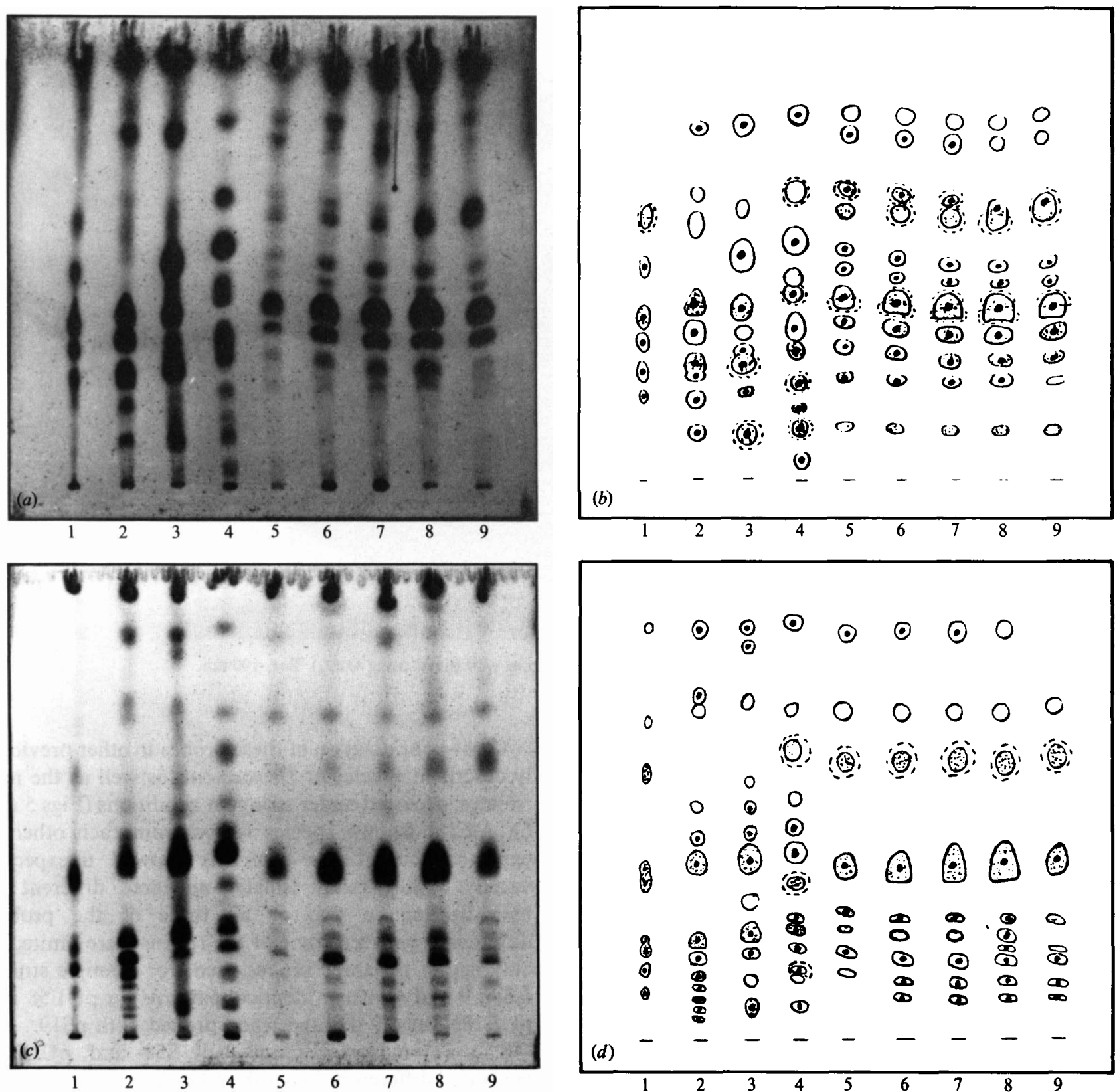

Fig. 4. TLC of polar lipids. (a) TLC of lipid extracts developed in solvent 1 and acid charred. (b) Diagram reaction to detection sprays following TLC of lipid extracts developed in solvent 1. (c) TLC of lipid extracts developed in solvent 2 and acid charred. (d) Diagram of reaction to detection sprays following TLC of lipid extracts developed in solvent 2 . Reaction to detection sprays is indicated as follows: - Positive for $\alpha$-naphthol and Bial's reagent; $S$, ninhydrin positive;, phosphate positive. Lanes: $1, D$. radiopugnans; $2, D$. radiodurans; 3 , $D$. radiophilus; 4 , D. proteolyticus; $5,1 / 10 ; 6,5 / 3 ; 7,6 / 1 ; 8,4 / 1 ; 9,4 / 12$.

nans isolates, strain $4 / 9$, and the type strain of the genus, $D$. radiodurans $\mathrm{R} 1$, were heavily $\mathrm{UV}$-irradiated ( $1500 \mathrm{~J}$ $\mathrm{m}^{-2}$ ). Eight colony isolates of $D$. radiopugnans strain $4 / 9$ survivors and 11 colony isolates of $D$. radiodurans $\mathrm{R} 1$ survivors, as well as unirradiated controls, were evaluated by the same RFLP procedures as used for the new isolates above. In the case of $D$. radiopugnans $4 / 9$, hybridization of all three probes was precisely identical amongst all eight $4 / 9$ survivors and the unirradiated 4/9 control. The same results were found in the case of $D$. radiodurans $\mathrm{R} 1$, i.e. all survivors and the unirradiated control were precisely identical. 

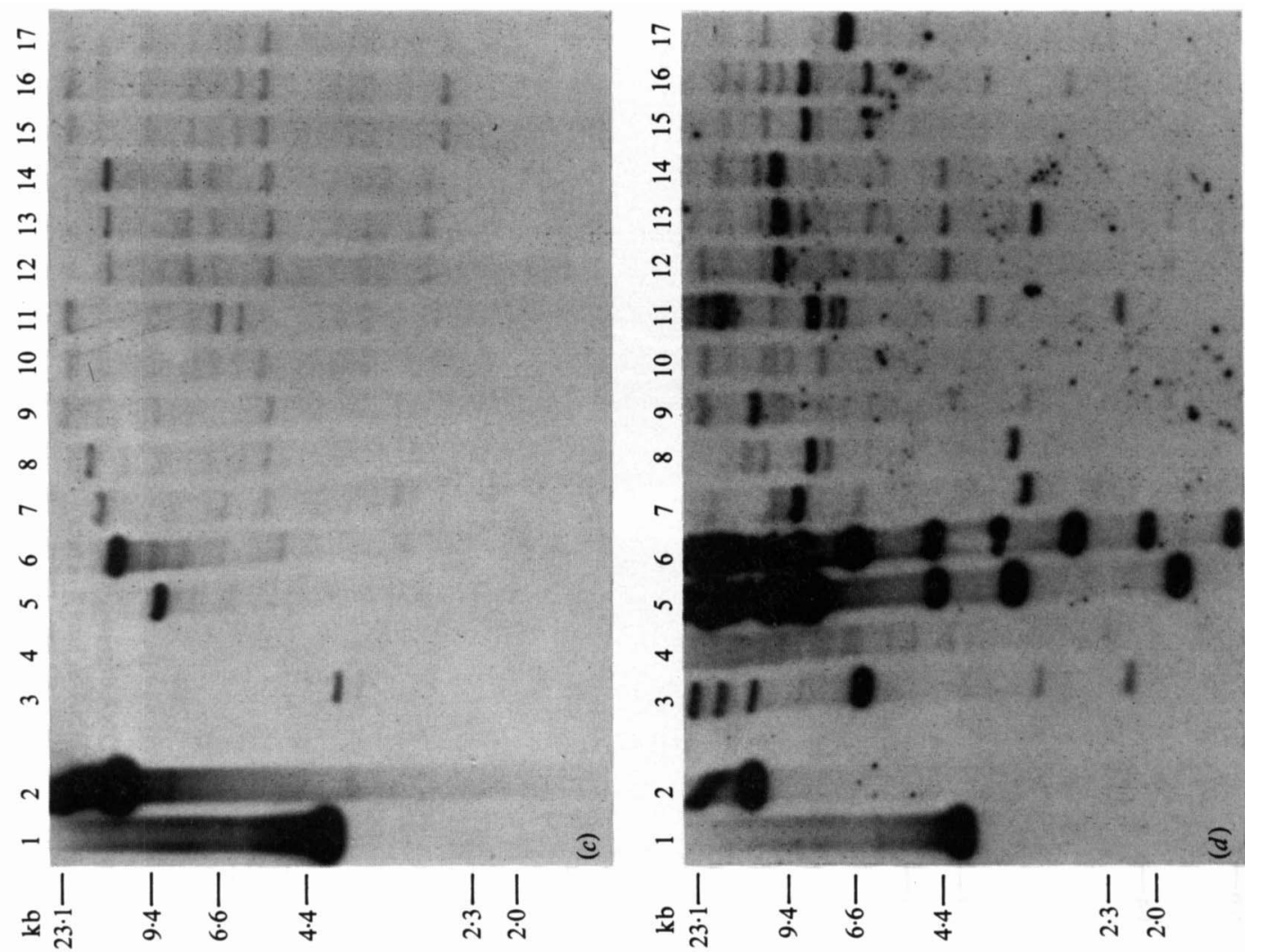

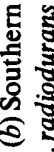

.

焉

हี

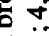

氬

氙 ญ。

인

过

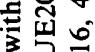

वृ 嫽 ชิ 远前 $=\overline{7}$

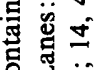
¿ $\vec{a}$

षे

氝

造
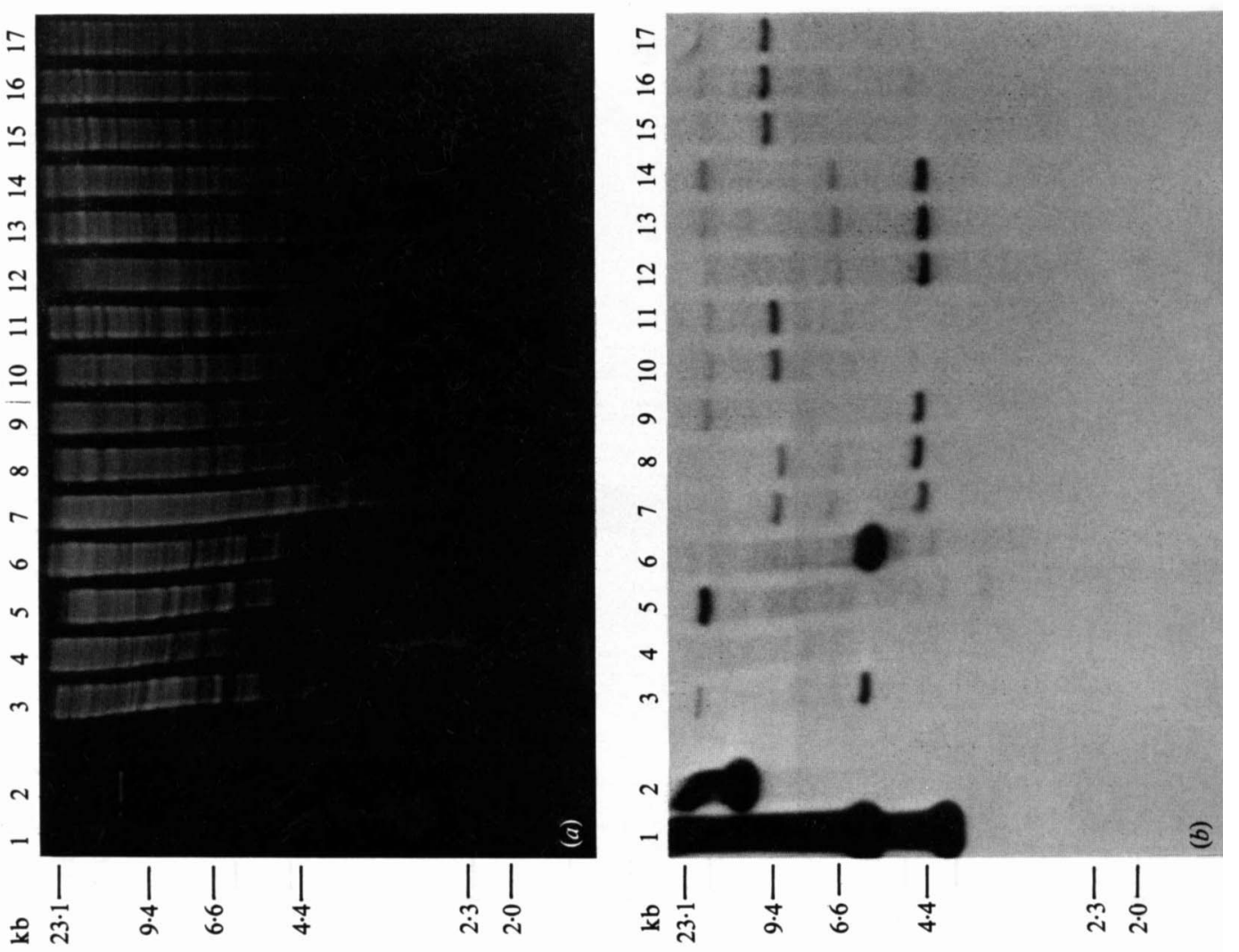

త

品范

造

焉

苛守

유은

홍

융

됙응

氧 .9 造 을 흥흥

苞是 品㐫 过 舲 出 은

동

a 용 

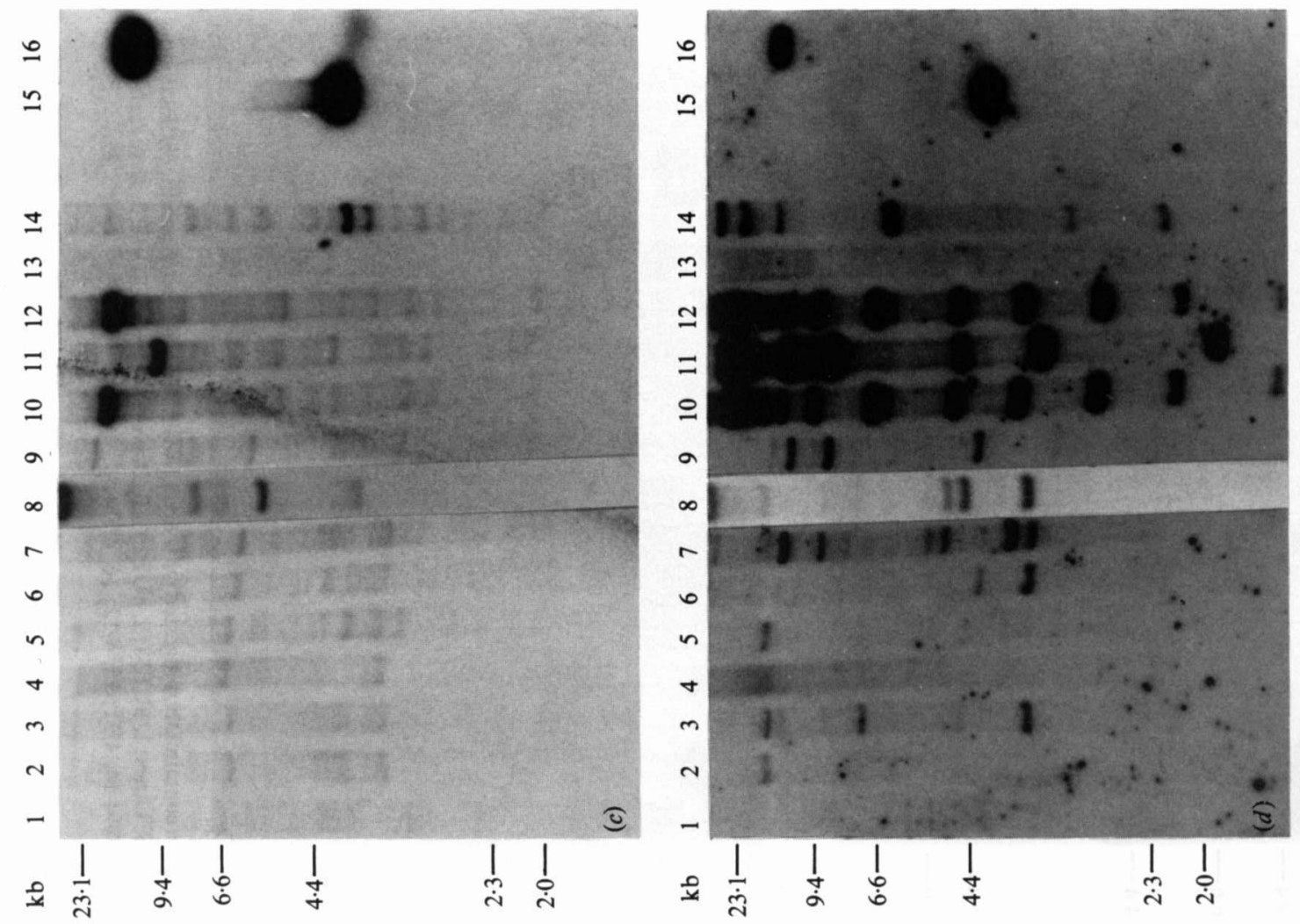

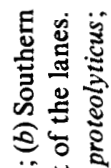

至

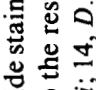

突要

E

:

衰放

उ를

政

造

政

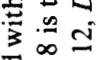

8

案

然

艺艺

完

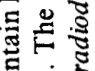

8

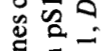

可

ष $3 \frac{2}{2}$

बิ

岩

흥

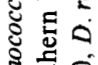

.

ธัฐ

宇京

ह $\dot{\delta} \ddot{~}$

듀

可

遂

要 可

$\therefore 5$

范 $\frac{0}{n}$

递。

至

흥

至

要的

苋施

논

垭 염 空出

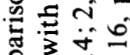

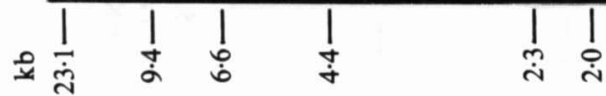


Table 2. RFLP groups

The division into RFLP groups is analysed sequentially: first pUE58, then pUE200, and finally pS19. Strains are listed under a probe only if that probe differentiated a new polymorphism group not already distinguished by a prior probe. Probes pUE200 and pS19 showed multiple polymorphisms amongst isolates already differentiated by pUE58 (Figs. $4 c, d, 5 c, d$ ).

\begin{tabular}{clcl}
\hline \hline Group & \multicolumn{1}{c}{ Probe pUE58 } & Probe pUE200 & Probe pS19 \\
\hline 1 & $1 / 10$ & & \\
2 & $4 / 1,4 / 5$ & $4 / 1$ & \\
3 & & $4 / 5$ & \\
4 & $4 / 8,4 / 9,4 / 11$ & & $4 / 8,4 / 11$ \\
5 & & $4 / 9$ \\
6 & $4 / 12,4 / 13,4 / 16$ & $4 / 12,4 / 13$ \\
7 & & & \\
8 & $5 / 1$ & & \\
9 & $5 / 3$ & \\
10 & $5 / 5$ & $5 / 6$ \\
11 & $5 / 6,5 / 9,5 / 10,5 / 13$ & $5 / 9$ \\
12 & & $5 / 13$ \\
13 & & \\
14 & & \\
15 & $5 / 7$ & \\
16 & $5 / 14$ & \\
17 & $6 / 1$ & \\
\hline \hline
\end{tabular}

\section{Discussion}

This work identifies a new set of 19 isolates of Deinococcus from the UK. In phenotypic characteristics the isolates conformed most closely with $D$. radiopugnans. Eighteen of these colony isolates were obtained from three closely adjacent $2 \mathrm{~g}$ samples of damp soil next to a lake in Nottingham. Investigation of the 19 isolates for RFLPs using three probes revealed that almost every one was unique (Table 2). The plasmid pUE58 contains the $m t c A$ gene, and pUE200 the uvsC, uvsD and uvsE genes from $D$. radiodurans $\mathrm{R} 1$. The gene products of these loci are two independent UV-endonucleases that are required for resistance to UV and bulky alkylating agents (Evans \& Moseley, 1983; Moseley \& Copland, 1978; Moseley \& Evans, 1983; Tempest \& Moseley, 1980 ), and we expected them to be highly conserved as all members of the genus are remarkably UV-resistant (Moseley, 1983). The third probe, pS19, is the full length of the naturally occurring $D$. radiodurans SARK cryptic plasmid pUE11, which has been cloned in the E. coli plasmid pS27 (Smith et al., 1989).

Cross-hybridization of $\mathrm{pS} 19$ with chromosomal DNA of $D$. radiodurans strains SARK and $\mathrm{R} 1$, and hybridization to pS16, a cryptic plasmid of strain $\mathrm{R} 1$, had led to the speculation that pUE11 and pS16 may be related episomes in their respective host strains (Smith et al., 1990). There are four EcoRI sites in pUE11; however, hybridization to EcoRI-cleaved genomic DNA of strains R1 and SARK results in the appearance of numerous bands under stringent conditions (Figs $5 d$ and $6 d$; Smith et al., 1989, 1990). Therefore, the results of hybridization with pS19 may reflect both plasmid and chromosomal polymorphisms.

Site 4 yielded six different strains, while site 5 , a few metres away, yielded nine different strains, with no overlap of RFLP types between these two adjacent soil samples. The two samples, though very close, may represent isolated populations, allowing variation to occur; but this does not account for the differences found within each sample.

To our knowledge, the extent of diversity of laboratory-grown colony isolates from single samples (either environmental or clinical) as shown in the current work, has not been previously demonstrated for any other bacteria. A wide spectrum of studies have addressed bacterial diversity by RFLP analysis, but in all cases there has been little diversity (Clark-Curtiss \& Walsh, 1989; Kakoyiannis et al., 1984), or in those studies in which extensive diversity was demonstrated it was attributable to host specificity (Fukushi \& Hirai, 1989; Kaijalanin \& Lindstrom, 1989), isolations from widely different sites, or the importation of new strains in animals or humans from other sites (Kakoyiannis et al., 1984; Caufield \& Walker, 1989; Saunders et al., 1990; Harrison et al., 1990; van Ketel et al., 1984; Steele et al., 1990; LiPuma et al., 1989).

The large number of $D$. radiopugnans strains from a small sample, as distinguished by RFLPs, is unlikely to be the result of point mutations adding and subtracting EcoRI sites in the chromosome. Instead, our observation suggests the frequent occurrence of chromosomal rearrangements. We have recently detected highly conserved long reiterated sequences widely distributed in the chromosomes of both $D$. radiodurans SARK (Lennon et al., 1991) and R1 (unpublished results). These sequences could serve as recombination sites at which rearrangements occur. It can also be speculated that bacteriophages or transposons induce rearrangements; however, despite intense efforts to identify such agents over many years, none have been found (unpublished results).

This study suggests much greater heterogeniety of genomes within $D$. radiopugnans than ever previously imagined. Typically, if multiple isolates cultured from a single natural sample appear identical by classical methods, it is tacitly assumed that these isolates are monoclonal. If at any point during the course of this study we had taken one colony as representative, we would have failed to detect the diversity of chromosomal arrangement in these isolates. The frequency of rearrangements in $D$. radiopugnans may be species- or genusspecific. Alternatively, thorough characterization of natural isolates from single sources of other bacterial species may reveal similar phenomena. 
The polar lipid assessment was undertaken with the assistance of $T$. J. Counsell and the electron microscopy was performed with the assistance of M. Hall and D. Moyles. We are grateful to Walter Chung and the facilities of the Department of Biochemistry, University of Western Ontario, for the amino acid analyses. We thank David Evans for pUE200.

R.G.E.M. is appreciative of the long-term support of his research and the electron microscope facility by the Medical Research Council of Canada. C.I.M. and K.W.M. are supported by USPHS grant GM39933.

\section{References}

Al-Bakri, G. H., Mackay, M. W., Whittaker, P. A. \& Moseley, B E. B. (1985). Cloning of the DNA repair genes $m t c A, m t c B, u v s B$, $u v s D$, uvsE, and the leuB gene from Deinococcus radiodurans. Gene 33, 305-311.

Anderson, A. W., Norden, H. C., Cain, R. F., Parrish, G. \& DugGan, D. (1956). Studies on a radio-resistant micrococcus. I. Isolation, morphology, cultural characteristics, and resistance to gamma radiation. Food Technology 10, 575-578.

Bligh, E. G. \& DYER, W. J. (1959). A rapid method of total lipid extraction and purification. Canadian Journal of Biochemistry and Physiology 31, 911-917.

Brooks, B. W. \& Murray, R. G. E. (1981). Nomenclature for Micrococcus radiodurans and other radiation-resistant cocci: Deinococcaceae fam. nov. and Deinococcus gen. nov., including five species. International Journal of Systematic Bacteriology 31, 353-360.

Brooks, B. W., Murray, R. G. E., Johnson, J. L., Stackebrandt, E., WoEse, C. R. \& Fox, G. E. (1980). Red-pigmented micrococci: a basis for taxonomy. International Journal of Systematic Bacteriology 30, 627-646.

Caufield, P. W. \& Walker, T. M. (1989). Genetic diversity within Streptococcus mutans evident from chromosomal DNA restriction fragment polymorphisms. Journal of Clinical Microbiology 27, 274 278.

Clark-Curtiss, J. E. \& Walsh, G. P. (1989). Conservation of genomic sequences among isolates of Mycobacterium leprae. Journal of Bacteriology 171, 4844-4851.

Counsell, T. C. \& MURRaY, R. G. E. (1986). Polar lipid profiles of the genus Deinococcus. International Journal of Systematic Bacteriology 36, 202-206.

Davis, N. S., Silverman, G. J. \& Masurovsky, E. B. (1963). Radiation resistant, pigmented coccus isolated from Haddock tissue. Journal of Bacteriology 86, 294-298.

Evans, D. M. \& Moseley, B. E. B. (1983). Roles of the uvsC, uvsD, $u v s \mathrm{E}$, and $m t c \mathrm{~A}$ genes in the two pyrimidine dimer excision repair pathways of Deinococcus radiodurans. Journal of Bacteriology 156, 576-583.

FUKUSHI, H. \& HIRAI, K. (1989). Genetic diversity of avian and mammalian Chlamydia psittaci strains and relation to host origin. Journal of Bacteriology 171, 2850-2855.

Giovannoni, S. J., Britschgi, T. B., Moyer, C. L. \& Field, K. G. (1990). Genetic diversity in Sargasso sea bacterioplankton. Nature, London 345, 60-63.

harrison, T. G., Saunders, N. A., Haththotuwa, A., Hallas, G., Birtles, R. J. \& TAYloR, A. G. (1990). Phenotypic variation amongst genotypically homogeneous Legionella pneumophilia serogroup I isolates: implications for the investigations of outbreaks of Legionaires' disease. Epidemiology and Infection 104, 171-180.

HUANG, Y. \& ANDERSON, R. (1989). Structure of a novel glucosaminecontaining phosphoglycolipid from Deinococcus radiodurans. Journal of Biological Chemistry 31, 18667-18672.

Ito, H., Watanabe, H., Takehisa, M. \& IrzuKa, H. (1983). Isolation and identification of radiation-resistant cocci belonging to the genus Deinococcus from sewage sludges and animal feeds. Agricultural and Biological Chemistry 47, 1239-1247.
KaIJALANin, S. \& LindsTrom, K. (1989). Restriction fragment length polymorphism analysis of Rhizobium galegae strains. Journal of Bacteriology 171, 5561-5566.

Kakoyiannis, C., Winter, P. J. \& Marshall, R. B. (1984). Identification of Campylobacter coli isolates from animals and humans by bacterial restriction endonuclease DNA analysis. Applied and Environmental Microbiology 46, 545-549.

VAN KetEL, R. J., TER SCHEGGETE, J. \& ZANEN, H. C. (1984). Molecular epidemiology of Legionella pneumophilia serogroup I. Journal of Clinical Microbiology 26, 362-364.

Kobatake, M., TANabe, S. \& HasegaWA, S. (1973). Nouveau Micrococcus radiorésistant à pigment rouge, isolé de féces de Llama glama, et son utilisation comme indicateur microbiologique de la radiosterilisation. Comptes Rendus des Séances de la Société de Biologie 167, 1506-1510.

LENNON, E. \& Minton, K. W. (1990). Gene fusions with lacZ by duplication insertion in the radioresistant bacterium Deinococcus radiodurans. Journal of Bacteriology 172, 2955-2961.

Lennon, E., Gutman, P. D., YaO, H. \& Minton, K. W. (1991). A highly conserved repeated chromosomal sequence in the radioresistant bacterium Deinococcus radiodurans SARK. Journal of Bacteriology 173, 2137-2140.

LEWIS, N. F. (1971). Studies on a radio-resistant coccus isolated from Bombay duck (Harpondon nehereus). Journal of General Microbiology 66, 29-35

LiPuma, J. J., Stull, T. L., Dasen, S. E., Pidcock, K. A., Kaye, D. \& KORZENIOWSKI, O. M. (1989). DNA polymorphisms among Escherichia coli isolated from bacteriuric women. Journal of Infectious Diseases 159, 526-532.

MARMUR, J. \& DOTY, P. (1962). Determination of the base composition of deoxyribonucleic acid from its thermal denaturation temperature. Journal of Molecular Biology 5, 109-118.

Moseley, B. E. B. (1983). Photobiology and radiobiology of Micrococcus (Deinococcus) radiodurans. Photochemistry and Photobiology Reviews 7, 223-274.

Moseley, B. E. B. \& Copland, H. J. R. (1978). Four mutants of Micrococcus radiodurans defective in the ability to repair DNA damaged by mitomycin-C, two of which have wild-type resistance to ultraviolet radiation. Molecular and General Genetics 160, 331-337.

Moseley, B. E. B. \& Evans, D. M. (1983). Isolation and properties of strains of Micrococcus (Deinococcus) radiodurans unable to excise ultraviolet light-induced pyrimidine dimers from DNA : evidence for two excision pathways. Journal of General Microbiology 129, 2437 2445.

MURRAY, R. G. E (1986). The biology and ecology of the Deinococcacea. In Perspectives in Microbial Ecology (Proceedings of the IV International Symposium on Microbial Ecology), pp. 153-158. Edited by F. Megusar \& M. Gantar. Ljubljana: Slovene Society for Microbiology

Murray, R. G. E. \& Brooks, B. W. (1986). Deinococcus. In Bergey's Manual of Systematic Bacteriology, vol. 2, pp. 1035-1043. Edited by P. H. A. Sneath \& J. G. Holt. Baltimore: William \& Wilkins.

Naumovski, L. \& Friedberg, E. C. (1982). Molecular cloning of eukaryotic genes required for excision repair of UV-irradiated DNA: isolation and partial characterization of the $R A D 3$ gene of Saccharomyces cerevisiae. Journal of Bacteriology 152, 323-331.

SANDERS, S. W. \& MAXCY, R. B. (1979). Isolation of radiation-resistant bacteria without exposure to radiation. Applied and Environmental Microbiology 38, 436-439.

Saunders, N. A., Harrison, T. G., Haththotuwa, A., Kachwalla, N. \& TAYLOR, A. G. (1990). A method for typing strains of Legionella pneumophilia serogroup I by analysis of restriction fragment length polymorphisms. Journal of Medical Microbiology 31, 45-55.

Schleifer, K. H. \& KandleR, O. (1972). Peptidoglycan types of bacterial cell walls and their taxonomic implications. Bacteriological Reviews 36, 407-477.

Smith, M. D., Abrahamson, R. \& Minton, K. W. (1989). Shuttle plasmids constructed by the insertion of an Escherichia coli cloning vector into two Deinococcus radiodurans plasmids. Plasmid 22, 132 142.

Smith, M. D., McNeil, L. B. \& Minton, K. W. (1990). Plasmid genetics and gene expression in Deinococcus radiodurans. In Genetic 
Transformation and Expression, pp. 125-131. Edited by L. O. Butler, C. Harwood \& B. E. B. Moseley. Andover, Hants, UK: Intercept.

Steele, T. W., Lanser, J. \& Sangster, N. (1990). Isolation of Legionella longbeachae serogroup I from potting mixes. Applied and Environmental Microbiology 56, 49-53.

TEMPEST, P. R. \& MoseLEY, B. E. B. (1980). Defective excision repair in a mutant of Micrococcus radiodurans hypermutable by some monofunctional alkylating agents. Molecular and General Genetics 179, 191-199.
TIRgari, S. \& Moseley, B. E. B. (1980). Transformation in Micrococcus radiodurans: measurement of various parameters and evidence for multiple independently segregating genomes per cell. Journal of General Microbiology 119, 287-296.

Ward, D. M., Weller, R. \& Bateson, M. M. (1990). 16S rRNA sequences reveal numerous uncultured microorganisms in a natural community. Nature, London 345, 63-65. 